\title{
Air pollution and health in Sri Lanka: a review of epidemiologic studies
}

\author{
Yatagama Lokuge S Nandasena*1, Ananda R Wickremasinghe² and Nalini Sathiakumar ${ }^{3}$
}

\begin{abstract}
Background: Air pollution is increasingly documented as a threat to public health in most developing countries. Evaluation of current air quality levels, regulatory standards and scientific literature on outdoor and indoor air pollution, and health effects are important to identify the burden, develop and implement interventions and to fill knowledge gaps in Sri Lanka.

Methods: PUBMED and Medline databases, local journals and conference proceedings were searched for epidemiologic studies pertaining to air pollution and health effects in Sri Lanka. All the studies pertaining to air pollution and health effects were considered.

Results: Sixteen studies investigated the association between exposure to ambient or indoor air pollution (IAP) and various health outcomes ranging from respiratory symptoms, low birth weight and lung cancers. Of the sixteen, three used a case control design. Half of the studies collected exposure data only through questionnaires. There were positive associations between air pollution and adverse health effects in all studies. Methodological limitations in most of the studies resulted in poor quantification of risk estimates.

Conclusion: A limited number of epidemiological studies in Sri Lanka have investigated the health effects of air pollution. Based on findings of studies and reported air quality levels, air pollution may be considered a neglected public health problem in Sri Lanka.
\end{abstract}

\section{Background}

Air pollution, both indoors and outdoors, is a major environmental health problem affecting people in both developed and developing countries. Although air pollutants are many, the most important are particle pollution (often referred to as particulate matter (PM)), ground-level ozone $\left(\mathrm{O}_{3}\right)$, carbon monoxide $(\mathrm{CO})$, sulfur oxides $\left(\mathrm{SO}_{\mathrm{x}}\right)$, nitrogen oxides $\left(\mathrm{NO}_{\mathrm{x}}\right)$, and lead $(\mathrm{Pb})$ which are found in the ambient air (also known as "criteria pollutants"); PM, $\mathrm{CO}, \mathrm{SO}_{\mathrm{x}}, \mathrm{NO}_{\mathrm{x}}$, environmental tobacco smoke (ETS), formaldehyde and polycyclic organic matter are found indoors [1,2].

Exposure to air pollutants leads to a variety of health effects depending on the type of pollutant, amount of the pollutant exposed to, duration and frequency of exposure, and associated toxicity of the specific pollutant.

* Correspondence: sumalnandasena@gmail.com

${ }^{1}$ Evaluation and Research Unit, National Institute of Health Sciences, Ministry of Health, Kalutara, Sri Lanka

Full list of author information is available at the end of the article
These exposures are associated with a broad range of acute and chronic health effects varying from sub-clinical effects to premature mortality [3]. Although air pollutants are categorized in a number of different ways, most air pollutants generally do not occur in isolation, but in complex mixtures that create the potential for synergistic effects among them [4]. The composition of air pollutants and their associated toxicity vary in different settings. Age, cultural practices, life style and socio-economic status may influence the exposure to air pollutants [4]. As the individual sensitivity to pollutants increases, the severity of the response will increase for a given pollutant. Therefore, the effects of air pollutants and the severity of health outcomes in a given population depend on the population sensitivities [3]. Hence, the health impact of air pollution on a given community cannot be directly generalized from results of studies in other settings.

Several population groups are more vulnerable to the effects of air pollutants; those who are innately susceptible more than others, those who become susceptible as a 
result of environmental, social and personal behaviours, and those who are simply exposed to unusually large amounts of air pollutants [5]. Groups that are more sensitive to air pollutants include unborn and young children, elderly people, and those with a history of cardio-respiratory diseases [5]. Hence, the demographic profile of a given population is also important.

Although air pollution is recognized as an emerging public health problem in developing countries, most of these countries do not have adequate data to evaluate the actual magnitude of the problem. The main reason may be that air pollution co-exists with other important public health problems, such as communicable diseases, vectorborne diseases, malnutrition and poor sanitation, which are given higher priority in circumstances where economic resources are limited. This has delayed the actions needed to adequately assess, evaluate and control air pollution [4]. The Sri Lankan situation is no different to other developing countries.

Our primary interests were to explore the air quality levels and review the literature regarding health effects due to air pollution in Sri Lanka. In the first part of this review, we discuss air quality, control measures implemented, and air quality regulations in Sri Lanka separately for ambient and indoor air. Secondly, we review the studies pertaining to health effects due to air pollution in Sri Lanka.

\section{Ambient air pollution}

Ambient air pollution, especially in urban environments, arises from a spectrum of different sources, which are broadly classified as stationary, mobile, and area emission sources. The main source of ambient air pollution in Sri Lanka is vehicular emissions, which contributes to over $60 \%$ of total emissions in Colombo [6].

Measures have been taken to reduce outdoor air pollution due to vehicular emissions. The National Policy on Urban Air Quality Management was adopted in 2000. The phasing out of leaded gasoline in June 2002, introduction of low sulphur diesel in January 2003, banning the importation of Two Stroke Three-wheelers in 2008, and initiation of vehicular emission testing programme in year 2008 are some key steps that have been taken to control urban outdoor air pollution in Sri Lanka. The permissible ambient air quality standards for selected air pollutants were for the first time enacted under the National Environmental (Ambient Air Quality) Regulations of 1994 [7]. With the publication of WHO air quality guidelines in 2005[8], air quality standards for Sri Lanka, including standards for $\mathrm{PM}_{10}$ and $\mathrm{PM}_{2.5}$, were amended and gazetted in August 2008[9] (Table 1).

Despite many discussions to expand air quality monitoring in Sri Lanka, there has been only one station located at Colombo Fort, since 1997, to monitor ambient air quality on a continuous basis. Based on data from this station, the average annual ambient $\mathrm{PM}_{10}$ levels in Colombo over the years have remained relatively stable ranging from 72 to $82 \mu \mathrm{g} / \mathrm{m}^{3}$ (Figure 1). The World Health Organization (WHO) recommends that the average annual ambient $\mathrm{PM}_{10}$ level be $<20 \mu \mathrm{g} / \mathrm{m}^{3}[8]$. Comparison of coarse particle mass concentrations of the Asian region under the Regional Co-operation Agreement (RCA) shows that the three-year average values reported from Colombo Fort (an urban location) was $73.37 \mu \mathrm{g} / \mathrm{m}^{3}$ and in a residential area was $58.82 \mu \mathrm{g} / \mathrm{m}^{3}$ from 2002 to 2005. Special 24-hour measurements for the purpose of the inter-country comparison were carried out at the Colombo Fort monitoring station on a weekly basis using the Gent stacked filter unit particle samplers. The values reported from other regional locations (used the same methodology and instruments) were: Bangladesh urban location - $45.76 \mu \mathrm{g} / \mathrm{m}^{3}$; India-Trombay - $37.34 \mu \mathrm{g} / \mathrm{m}^{3}$; India-Vashi - $82.83 \mu \mathrm{g} / \mathrm{m}^{3}$; Pakistan - $67.45 \mu \mathrm{g} / \mathrm{m}^{3}$, Thailand, urban - $38.67 \mu \mathrm{g} / \mathrm{m}^{3}$, Thailand, suburban - $25.77 \mu \mathrm{g} /$ $\mathrm{m}^{3}$ and Vietnam - $50.29 \mu \mathrm{g} / \mathrm{m}^{3}$ [10]. Another comparison of several cities around the world reported that the $\mathrm{PM}_{10}$ and $\mathrm{SO}_{2}$ levels in Colombo (based on the Colombo Fort monitoring station) is unhealthier than cities such as Hong Kong, Singapore, Bangkok Taipei and Tokyo, and the $\mathrm{PM}_{10}$ levels in Colombo are similar to that of $\mathrm{Ho} \mathrm{Chi}$ Minh, Jakarta and Mumbai [11]. Hourly averages of $\mathrm{SO}_{2}$ have exceeded the Sri Lankan standards on 177 occasions from May 2003 to December 2006. The annual mean levels of $\mathrm{SO}_{2}$ have not exceeded the USEPA limit of $80 \mu \mathrm{g} /$ $\mathrm{m}^{3}$, but the levels have shown an increasing trend in the last few years (Figure 2). $\mathrm{NO}_{2}$ levels in the Colombo city over the past few years have shown an increasing trend although the levels did not exceed the Sri Lankan standards (Figure 3). High levels of air pollutants were recorded during the North East monsoon period which lasts from mid November to January over the years [12]. $\mathrm{CO}$ and $\mathrm{O}_{3}$ levels were relatively low in Colombo as compared to other air pollutants [13]. Many criticisms have been expressed with reference to the Colombo Fort monitoring station underestimating air quality in the Colombo city area. Some of the criticisms include the location of the monitoring station being not more than $800 \mathrm{~m}$ from the sea, which causes the shedding off of pollutants due to wind, shifting of high traffic towards the interior of the country due to prevailing high security zone in its vicinity, and newly established factories and power plants being situated several kilometres away from the monitoring station.

The National Building Research Organization of Sri Lanka established a passive air quality monitoring net- 
Table 1: Sri Lankan air quality standards

\begin{tabular}{|c|c|c|}
\hline Air pollutant & Average time & Sri Lankan standard $\left(\mu \mathrm{g} / \mathrm{m}^{3}\right)$ \\
\hline \multirow[t]{3}{*}{ Carbon monoxide } & $8 \mathrm{hr}$ & 10000 \\
\hline & $1 \mathrm{hr}$ & 30000 \\
\hline & Any time & 58000 \\
\hline \multirow[t]{3}{*}{ Nitrogen dioxide } & $24 \mathrm{hr}$ & 100 \\
\hline & $8 \mathrm{hr}$ & 150 \\
\hline & $1 \mathrm{hr}$ & 250 \\
\hline \multirow[t]{3}{*}{ Sulfur dioxide } & $24 \mathrm{hr}$ & 80 \\
\hline & $8 \mathrm{hr}$ & 120 \\
\hline & $1 \mathrm{hr}$ & 200 \\
\hline Ozone & $1 \mathrm{hr}$ & 200 \\
\hline \multirow[t]{2}{*}{ Lead } & Annual & 0.5 \\
\hline & $24 \mathrm{hr}$ & 2 \\
\hline \multirow[t]{5}{*}{ SPM } & Annual & 100 \\
\hline & $24 \mathrm{hr}$ & 300 \\
\hline & $8 \mathrm{hr}$ & 350 \\
\hline & $3 \mathrm{hr}$ & 450 \\
\hline & $1 \mathrm{hr}$ & 500 \\
\hline \multirow[t]{2}{*}{$\mathrm{PM}_{2.5}$} & $24 \mathrm{hr}$ & 50 \\
\hline & Annual & 25 \\
\hline \multirow[t]{2}{*}{$\mathrm{PM}_{10}$} & $24 \mathrm{hr}$ & 100 \\
\hline & Annual & 50 \\
\hline
\end{tabular}




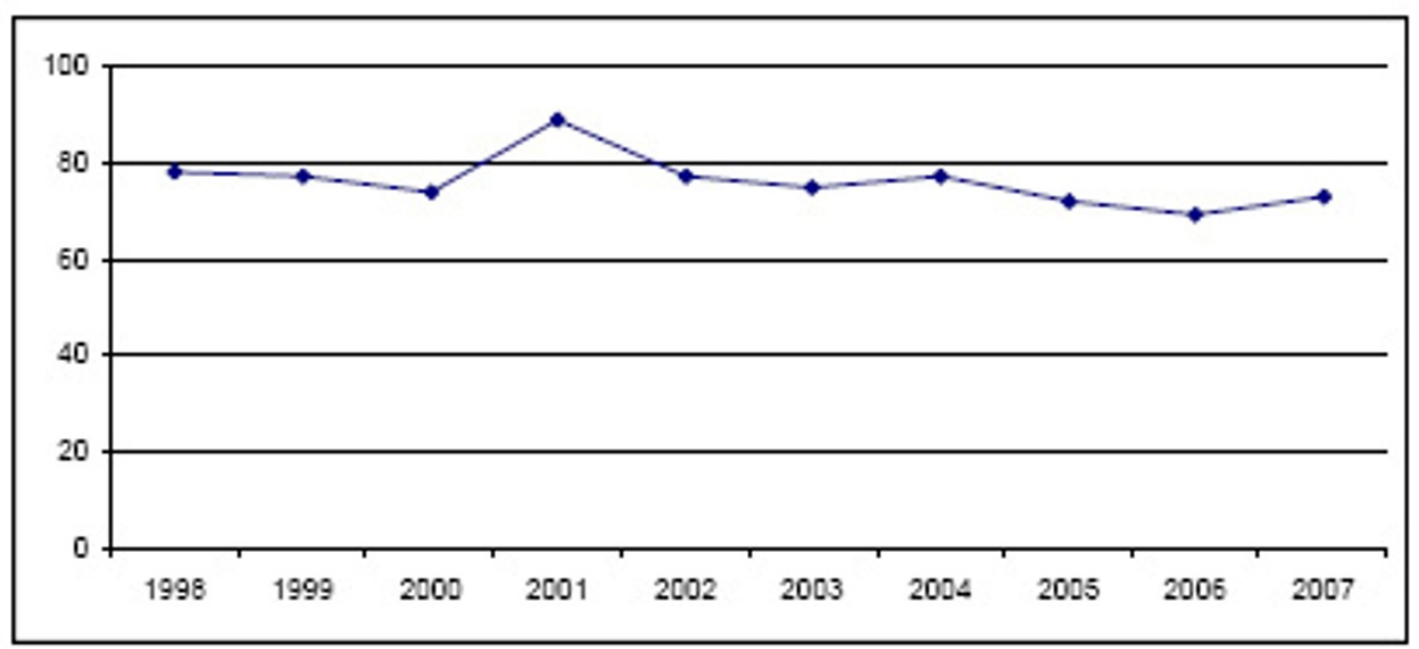

Figure 1 Annual averages of PM-10 at Colombo Fort ambient air quality monitoring Station (1998-2007). Source: Central Environmental Authority (Year 2007).

work in 2001 covering 15 locations in the Colombo city to monitor $\mathrm{SO}_{2}$ and $\mathrm{NO}_{2}$ [14]. Mallikarachchi et al [15], and Manawadu and Wijesekara [16] showed that the air quality of Colombo city was significantly associated with land transport density, population and building density by modelling air quality in the Colombo city, using data from the passive sampling air quality monitoring network.

\section{Indoor air pollution}

Indoor exposures are a result of complex interactions between the structure, building systems, indoor source strength, removal and deposition rate within the structure, indoor mixing and chemical reactions, furnishings, the outdoor environment, and the practices and the behaviours of the inhabitants [17]. High pollutant concentrations can result inside a closed indoor environment

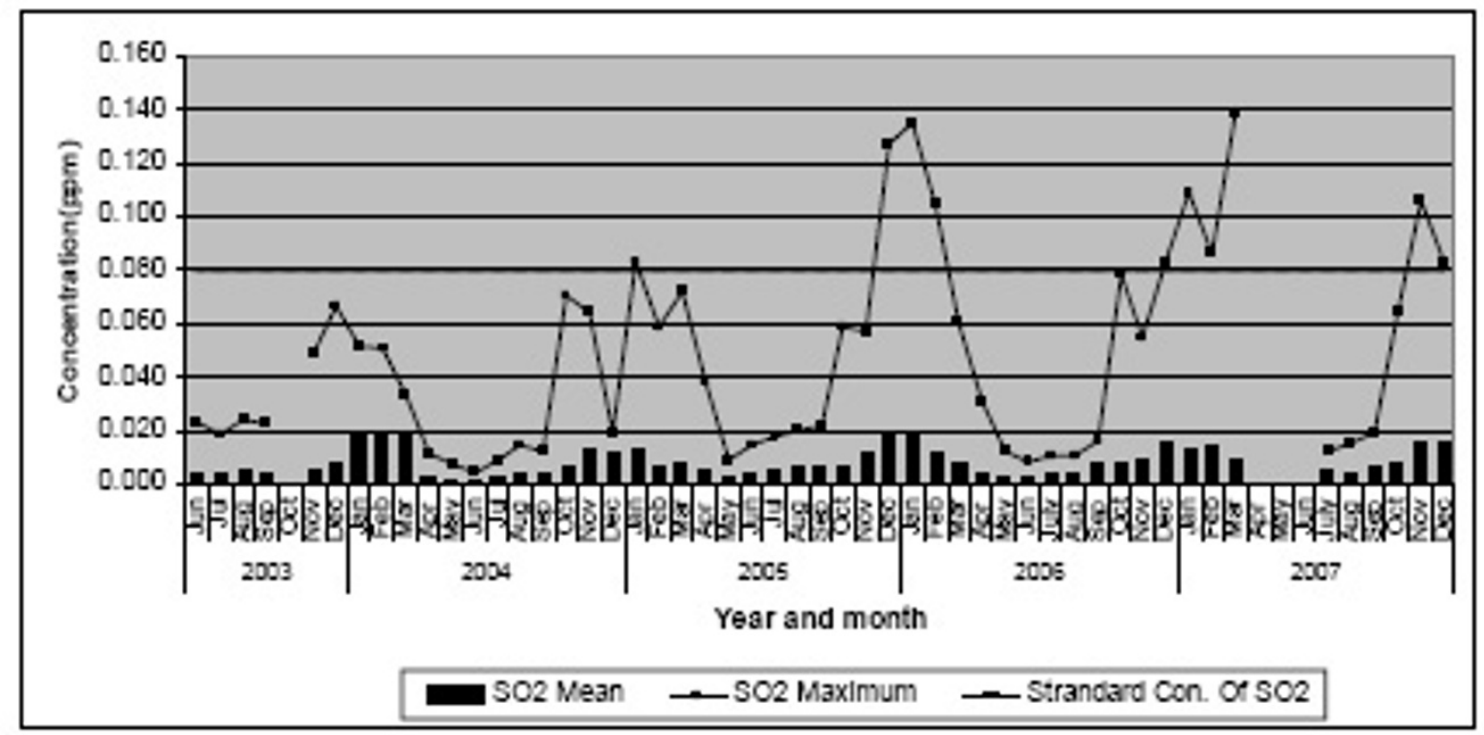

Figure 2 Monthly mean sulfur dioxide concentrations at Colombo Fort (June 2003 - December 2007). Source: Central Environmental Authority (2007). 


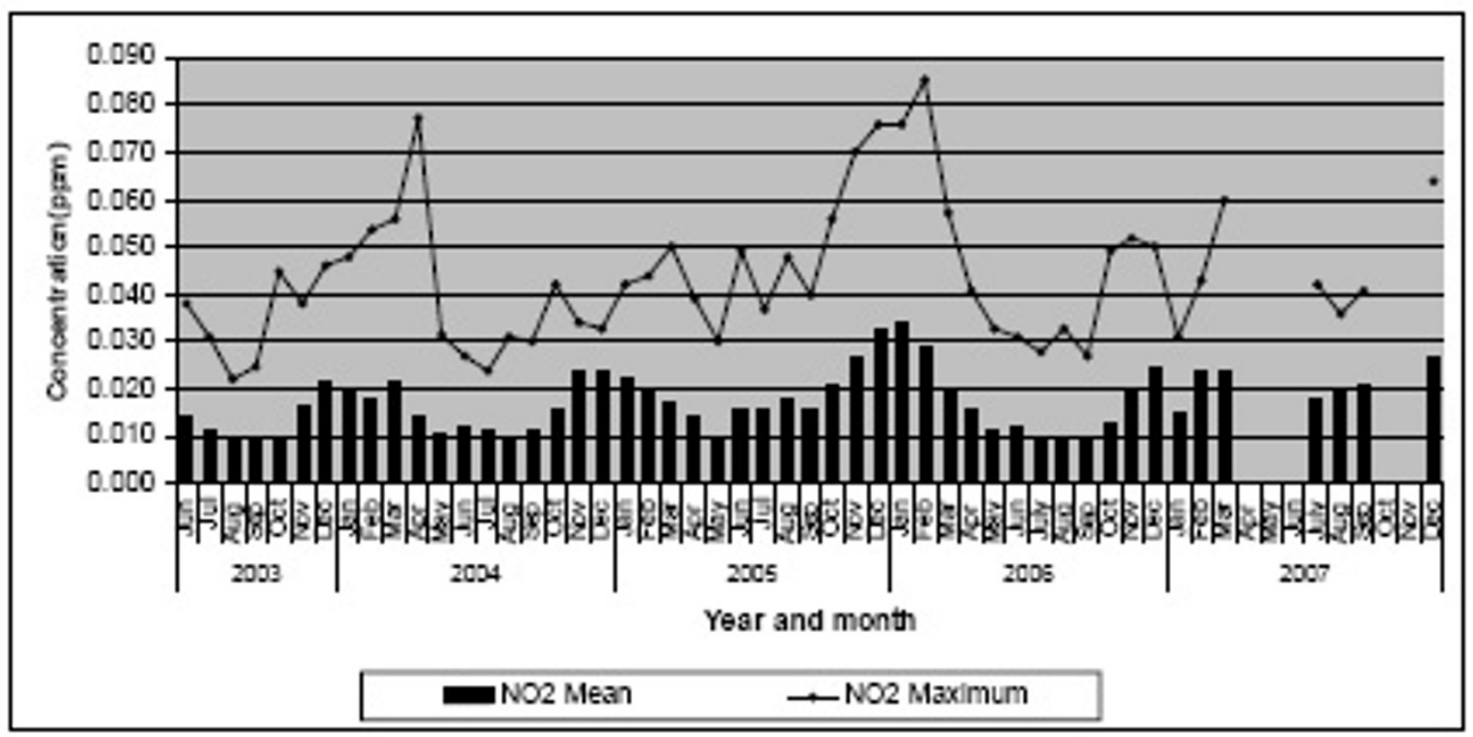

Figure 3 Monthly mean of one-hour averages of nitrogen dioxide concentrations at Colombo Fort (June 2003 - December 2007). Source: Central Environmental Authority (Year 2007).

even with relatively modest emissions. When the windows are open and the wind speed is moderate or high, the indoor concentrations of air pollutants may be the same as that outdoors [18]. Although Sri Lanka being a tropical country is expected to have good indoor ventilation, limited data suggest that indoor air is more polluted than outdoor air $[19,20]$.

Cooking fuel is the main source of IAP in households [21] while other sources include tobacco smoke and smoke from other outdoor sources [1]. The types of fuel typically increase in cleanliness, convenience, efficacy and cost as people move up the "energy ladder" [1]. According to the Demographic and Health Surveys of Sri Lanka of 2000 and 2007, firewood is the principal type of cooking fuel in $78.3 \%$ and $78.5 \%$ of the households in Sri Lanka, respectively [22]. It is unlikely that a higher proportion of Sri Lankans will shift to cleaner fuels in the near future [23]. Most of the traditional local stoves using firewood have incomplete combustion resulting in high pollutant emissions. This coupled with poor ventilation can produce very high levels of indoor pollution [24]. A study assessing exposure in kitchens using firewood with traditional stoves reported average $\mathrm{PM}_{2.5}$ concentrations exceeding $1200 \mu \mathrm{g} / \mathrm{m}^{3}$ [24]. A reduction of IAP was shown by the use of improved wood stoves in various settings in Sri Lanka [24] although the use of these stoves at the community level is almost negligible. Women and young children who usually stay around their mothers while cooking may be the most vulnerable to IAP due to cooking fuel.

A cross sectional study conducted to measure $\mathrm{SO}_{2}$ and $\mathrm{NO}_{2}$ levels indoors and outdoors of 30 low-income households at five different locations in Colombo reported that indoor pollutant levels were higher than those outdoors in all households. In that study, parents maintained a daily activity diary for their 5 to 8 year-old children which showed that these children spent an average 41 hours (out of 48 hours) inside their houses during weekends. The health status of children was not assessed in this study [25]. Regular use of mosquito coils by $12 \%$ of households may be another source of IAP [22] especially in poorly ventilated houses; the health impact of this exposure has not been investigated in Sri Lanka.

The National Authority on Tobacco and Alcohol (NATA) Act [26] banned smoking in health-care institutions, educational institutions, government facilities, universities, indoor offices, and other indoor workplaces. The Global Youth Tobacco Survey (GYTS) reported that there is no marked reduction in second-hand smoke in public places following the implementation of the NATA Act [27]. The GYTS further reported that there is a reduction in the prevalence of parental smoking from $1999(50.8 \%, 95 \% \mathrm{CI}=47.8 \%-53.8 \%)$ to 2007 (29.9\%, $95 \%$ $\mathrm{CI}=25.6 \%-34.5 \%)$. With almost one third of parents currently smoking, second-hand smoke in households may still be high and need to be explored quantitatively. 


\section{Methods}

\section{Search strategy}

We searched literature from PUBMED and MEDLINE databases to identify all relevant publications prior to June 2009. The following search terms were used: "ambient air pollution AND Sri Lanka", "indoor air pollution AND Sri Lanka", "air pollution AND Sri Lanka", "epidemiologic studies AND Sri Lanka", "health effects AND Sri Lanka."

We manually identified additional studies published in local journals and included conference proceedings which were inaccessible via the electronic databases. Reference lists of original studies were checked for related studies (cross reference). Authors of selected studies were contacted to identify additional literature.

\section{Study selection}

We included all studies relating to health effects due to air pollution in Sri Lanka irrespective of the study design. Studies that actually measured air quality levels and studies using proxy variables to predict air quality, indoors, outdoors or both, were included. We excluded studies which did not have health outcomes, and studies presented as conference proceedings which were not supplemented with a full report. We considered only the studies published in English as there are no scientific journals or any scientific literature available in the local languages. Preliminary results of ongoing studies were not considered.

\section{Data extraction}

Two investigators reviewed each paper independently. Discrepancies were discussed and agreement was achieved with consensus. Papers were categorised as indoor or outdoor based on the methodology. Studies were further categorised according to the study design. The following information from each study was abstracted: study location, exposure assessment, health outcomes, other risk factors evaluated, study results and limitations.

\section{Results and Discussion Study Characteristics}

We retrieved 65 publications and conference proceedings of potential interest, of which, 38 were excluded initially as they did not have a health outcome resulting from air pollution. Duplications of studies as publications and conference proceedings were taken as a single study. We finally identified 17 original studies. One study was excluded as we were unable to find the full report of the abstract presented in the conference proceeding (Figure 4). Studies included are summarized in Tables 2 \& 3 . Ten and six studies focussed on outdoor air pollution (Table
2) and indoor air pollution (Table 3), respectively. Nine studies had used a cross-sectional study design. Most of the health outcome studies show positive associations between air pollution and various adverse health effects, which correspond to results from studies conducted in other countries $[1,5]$. However, some studies have methodological limitations due to lack of objective measurement of personal exposures and indoor air quality leading to potential misclassification. Apart from age and sex, most studies do not adjust for potential confounding factors such as sources of air pollution other than those described in the study. Furthermore, possible factors which may influence indoor air pollution levels such as ventilation of houses, location of the kitchen, stove types and availability of exhaust mechanisms to expel the generated smoke from biomass fuel combustion, smoking inside households and mosquito coil use were poorly quantified (Figure 4).

\section{Studies on Ambient Air Pollution}

We identified 10 studies (Table 2) that examined the effect of ambient air pollution exposure on various respiratory health outcomes. Of the 10, 7 studies adopted a cross-sectional design. In all studies, questionnaires and/ or passive/active samplers were used to ascertain exposure. None of the studies used personal monitoring of exposure to ambient air. Other methodological limitations include small study sizes, potential misclassification of exposure, recall biases and inadequate adjustment for potential confounders.

\section{Respiratory health}

Sirithunga et al.[28] measured outdoor air pollutant levels in home environments of school children in an urban and a rural area in the Kandy district and assessed the respiratory symptoms over a one-year period on a daily basis using health diaries. Outdoor measurements representing a large area were obtained with passive samplers and indoor exposure relied on proxy parameters. The authors minimized recall bias by collecting information on the health conditions on a daily basis. The occurrence of cough, nasal discharge and throat irritation were 1.12 $(95 \% \mathrm{CI}=1.05-1.19), 1.17(95 \% \mathrm{CI}=1.09-1.24)$ and 1.48 $(95 \% \mathrm{CI}=1.31-1.67)$ times higher among children in the Kandy urban area, respectively, as compared to those of the rural area. Lung functions were also measured but there were no significant differences in the measurements between urban and rural subjects. The major limitation was the potential for exposure misclassification.

Premarathna et al. [29] studied the effects of air pollution on health of residents in an industrial area in Sri Lanka using a cross-sectional design and reported that the adult population living in the industrial area was 2.1 times more likely to have unexplained episodic cough 
Table 2: Studies assessing the health effects of ambient air pollution in Sri Lanka

\begin{tabular}{llllll}
$\begin{array}{l}\text { Reference, study } \\
\text { location and data } \\
\text { collection period }\end{array}$ & $\begin{array}{l}\text { Study design, subject } \\
\text { characteristics and } \\
\text { sample size }\end{array}$ & $\begin{array}{l}\text { Exposure air } \\
\text { pollutants }\end{array}$ & Health outcomes & Results & $\begin{array}{l}\text { Adjustment for } \\
\text { confounding factors }\end{array}$ \\
\hline
\end{tabular}

\section{Cross sectional studies}

Premaratna Retal. [29],

Gampaha district.

1997

Children, 1-12 years $(\mathrm{n}=\quad$ Not measured

154); adults ( $n=304)$

Senanayake MP et al.[37],

Colombo.

1998 and 2003

Children, 1-15 years

$2003, n=39)$

Amarasinghe J.N.P.et

al.[38],

Colombo.

2002

\section{Mistry R. et al.[32],}

Galle and Chandigarh.

2004

Children, 13-14 years

(Galle, $\mathrm{n}=1162$;

Chandigarh, $\mathrm{n}=575$ )

Nandasena YLS et al.[30],

Colombo and Ampara

482)

2005

Perera GBS et al.[35]

Colombo and Ampara

districts.

2005

Elangasinghe MA et

al.[31], Kandy.

2006

ildren, 9 - 15 years $(n$

Adults

$(\mathrm{n}=587)$

children

$(n=760)$
$(1998, n=50$;

$\mathrm{NO}_{2}$

Respiratory symptoms \& peak flow rate

Blood lead levels Blood lead levels

Policemen, traffic $(n=64) ; \quad$ Blood lead levels non-traffic $(n=64)$

$$
\begin{aligned}
& \mathrm{Nos} \\
& \text { are } \\
& \\
& \mathrm{SO}_{2} \\
& \mathrm{NO}_{2} \\
& \mathrm{PM}_{10}
\end{aligned}
$$

No specific types Wheezing are measured

$\mathrm{SO}_{2} \quad$ Respiratory symptoms

Potential symptoms and signs resulting from high blood lead levels

$\begin{array}{ll}\mathrm{SO}_{2} & \text { Respiratory symptoms } \\ \mathrm{NO}_{2} & \end{array}$

$\mathrm{NO}_{2}$

$\mathrm{PM}_{10}$

$\mathrm{PM}_{10}$
Higher rate of respiratory symptoms and reduction in expiratory flow rate reported in the industrialized area.

$6 \%$ of children had blood lead levels

$>10 \mu \mathrm{g} / \mathrm{dl}$ when leaded petrol was used (1998); none had levels > 10 $\mu \mathrm{g} / \mathrm{dl}$, one year after unleaded petrol was introduced.

Abdominal discomfort, tremor and hypertension higher in traffic policemen as compared to nontraffic policemen

Occurrences of wheezing was higher in Galle as compared to Chandigarh

Respiratory symptoms were higher in Colombo as compared to the rural area. Associations were overridden by household risk factors.

Occurrence of respiratory symptoms were higher in Colombo as compared to the rural area

$32 \%$ of children of village school had a health indicator of 1 (a measure of perfect respiratory health) while only $8 \%$ from the city school had an index of 1.
No measurement of exposure

Small sample size. Comparison of different birth cohorts.

Control group may also have had a high exposure during the busy hours

leading to

misclassification

No measurement of exposure

Adjusted for cooking fuel Only respiratory type and mosquito coil symptoms are use considered

Adjusted for cooking fuel Only respiratory type and mosquito coil symptoms are use considered.

No

Health indicator constructed by authors but not validated. 
Table 2: Studies assessing the health effects of ambient air pollution in Sri Lanka (Continued)

\section{Other Study Designs}

Senanayake, MP et al.[33], Ecological study, children $\quad \mathrm{NO}_{2}, \mathrm{SO}_{2}$

Lady Ridgeway Children's under 12 years ( $\mathrm{n}$

Hospital, Colombo.

$=41032$

1998-1999

Sirithunga TLC et al.[28],

Kandy district.

2004.

Follow-up study

children 7-12 years

$(n=1033)$

$\mathrm{SO}_{2}$

$\mathrm{NO}_{2}$

Thishan Dharshana KG

and Coowanitwong

$\mathrm{N}[34]$,

LRH hospital, Colombo.

Ecological study

$\mathrm{PM}_{10}$

2008
Emergency reporting for Episodes of nebulization

positively correlated with most

polluted days $(p<0.05)$

Respiratory symptoms

Occurrences of respiratory

symptoms were higher in the

Kandy city area as compared to the rural area.

Respiratory diseases

\section{Diseases categories included}

bronchitis, emphysema and other

chronic obstructive pulmonary

diseases; positive correlation $(r=$

$0.717 ; p=0.01$ )
No measurement of

exposure of the children;

pollutant data from

single monitor in the city

Only outdoor passive

samplers used; indoor air

quality predicted with

proxy variables

Colombo Fortmonitoring

station may not be

representative of the

whole study area. 
Table 3: Studies assessing the health effects of indoor air pollution in Sri Lanka

\begin{tabular}{|c|c|c|c|c|c|c|}
\hline $\begin{array}{l}\text { Reference, Study } \\
\text { Location and data } \\
\text { collection period }\end{array}$ & $\begin{array}{l}\text { Study Design } \\
\text { Subject } \\
\text { Characteristics } \\
\text { and sample size }\end{array}$ & $\begin{array}{l}\text { Exposure air } \\
\text { pollutants }\end{array}$ & $\begin{array}{l}\text { Health } \\
\text { outcomes }\end{array}$ & Results & $\begin{array}{l}\text { Adjustment for } \\
\text { confounding } \\
\text { factors }\end{array}$ & Limitations \\
\hline \multicolumn{7}{|l|}{ Cross sectional studies } \\
\hline $\begin{array}{l}\text { Karunasekara KAW et } \\
\text { al.[40], } \\
\text { Gampaha district. } \\
1998\end{array}$ & $\begin{array}{l}\text { Children, 5-11 } \\
\text { years, } \\
\text { asthmatics } \\
(\mathrm{n}=441) ; \\
\text { non asthmatics } \\
(\mathrm{n}=1510)\end{array}$ & $\begin{array}{l}\text { No specific types } \\
\text { are measured }\end{array}$ & Asthma & $\begin{array}{l}\text { Prevalence of } \\
\text { asthma was } \\
\text { significantly } \\
\text { higher in the } \\
\text { presence of } \\
\text { firewood smoke }\end{array}$ & Yes & $\begin{array}{l}\text { No measurement } \\
\text { of exposure }\end{array}$ \\
\hline $\begin{array}{l}\text { Lankatilake KN et al.[20], } \\
\text { Kotte Medical Officer of } \\
\text { Health area. } \\
1999\end{array}$ & $\begin{array}{l}\text { Households }=397 \\
\text { children }=604 \\
\text { women }=130\end{array}$ & Respirable dust & $\begin{array}{l}\text { Respiratory } \\
\text { symptoms }\end{array}$ & $\begin{array}{l}\text { Respiratory } \\
\text { symptoms were } \\
\text { significantly } \\
\text { higher in houses } \\
\text { using firewood }\end{array}$ & Yes & $\begin{array}{l}\text { Only respirable } \\
\text { dust levels were } \\
\text { measured }\end{array}$ \\
\hline $\begin{array}{l}\text { Pathirane S M et } \\
\text { al.[43]Kegalle and } \\
\text { Kalutara districts. } \\
2004\end{array}$ & $\begin{array}{l}\text { New borns } \\
(n=369)\end{array}$ & No specific types & $\begin{array}{l}\text { Low birth } \\
\text { weight }\end{array}$ & $\begin{array}{l}\text { Low birth weight } \\
\text { was associated } \\
\text { with fuel type and } \\
\text { kitchen } \\
\text { characteristics }\end{array}$ & No & $\begin{array}{l}\text { No measurement } \\
\text { of exposure }\end{array}$ \\
\hline \multicolumn{7}{|l|}{ Case-control Studies } \\
\hline $\begin{array}{l}\text { Karunasekara KAW et } \\
\text { al.[39], } \\
\text { Colombo North } \\
\text { Teaching Hospital } \\
\text { 1996-1997 }\end{array}$ & $\begin{array}{l}\text { Children 1-10 } \\
\text { years, } \\
\text { age matched } \\
\text { cases and controls } \\
(n=300)\end{array}$ & No specific type & Asthma & $\begin{array}{l}\text { Dust at home was } \\
\text { a significant risk } \\
\text { factor for asthma }\end{array}$ & Yes & $\begin{array}{l}\text { No measurement } \\
\text { of exposure }\end{array}$ \\
\hline $\begin{array}{l}\text { Perera MAKK P et al.[42], } \\
\text { National Cancer } \\
\text { Hospital } \\
2004\end{array}$ & $\begin{array}{l}\text { Lung cancer } \\
\text { patients }(n=128) \\
\text { and controls } \\
(n=128)\end{array}$ & No specific type & Lung cancer & $\begin{array}{l}\text { No significant } \\
\text { association with } \\
\text { biomass exposure }\end{array}$ & No & $\begin{array}{l}\text { No measurement } \\
\text { of exposure }\end{array}$ \\
\hline $\begin{array}{l}\text { Ranasinghe MH et } \\
\text { al.[41], National Eye } \\
\text { Hospital, Colombo } \\
2004\end{array}$ & $\begin{array}{l}\text { Patients with } \\
\text { cataracts }(n=197) \\
\text { and controls } \\
(n=190)\end{array}$ & No specific type & Cataract & $\begin{array}{l}\text { Cataracts } \\
\text { significantly } \\
\text { associated with } \\
\text { biomass exposure }\end{array}$ & No & $\begin{array}{l}\text { No measurement } \\
\text { of exposure }\end{array}$ \\
\hline
\end{tabular}

(95\% CI $=1.13-7.09)$ and a significant reduction in expiratory flow as compared to the adult population living in a non-industrial area. The younger population $(\leq 12$ years) living in the industrial area were 2.8 (95\% CI = 1.10-7.10) times more likely to have rhinitis as compared to the younger population living in the non-industrial area. These conclusions were based on the assumption that the industrialized area is more polluted compared to the control area. No air quality measurements were made to confirm this assumption.

School children are another group exposed to high levels of pollutants exaggerated by overcrowding of major schools in cities, especially in Colombo. The prevalence of respiratory symptoms among school children attending a school in Colombo situated close to a busy main road was significantly higher than that of children attending a school situated in a rural area (cough - OR $=1.33$,
95\% CI = 1.12-2.48; presence of phlegm - OR: $1.66,95 \%$ $\mathrm{CI}=1.12-2.46$; wheezing - OR: $1.29,95 \% \mathrm{CI}=0.80-2.10$ ). Children's exposure in the home environment was considered only by proxy parameters such as cooking fuel type and no adjustments were made for confounding factors. Air pollutant $\left(\mathrm{NO}_{2}, \mathrm{SO}_{2}\right.$, and TSP) levels were significantly higher in the premises of the urban school as compared to the rural school [30]. The respiratory health of school children (12 to 16 years), residing in and around Kandy city $(\mathrm{n}=770)$, was studied by measuring $\mathrm{PM}_{10}$ levels in a cross-sectional survey[31]. $\mathrm{PM}_{10}$ levels "outsidethe-city school" were lower (3-hour average, $84 \mathrm{mg} / \mathrm{m}^{3}$ ) as compared to the "city school" $\left(121 \mathrm{mg} / \mathrm{m}^{3}\right)$. An arbitrary health indicator of 1 , a measure of perfect health, was found among $32 \%$ of children of the "outside-the-city school" as compared to only $8 \%$ of children of the "city school". Misclassification of exposure is a potential limi- 


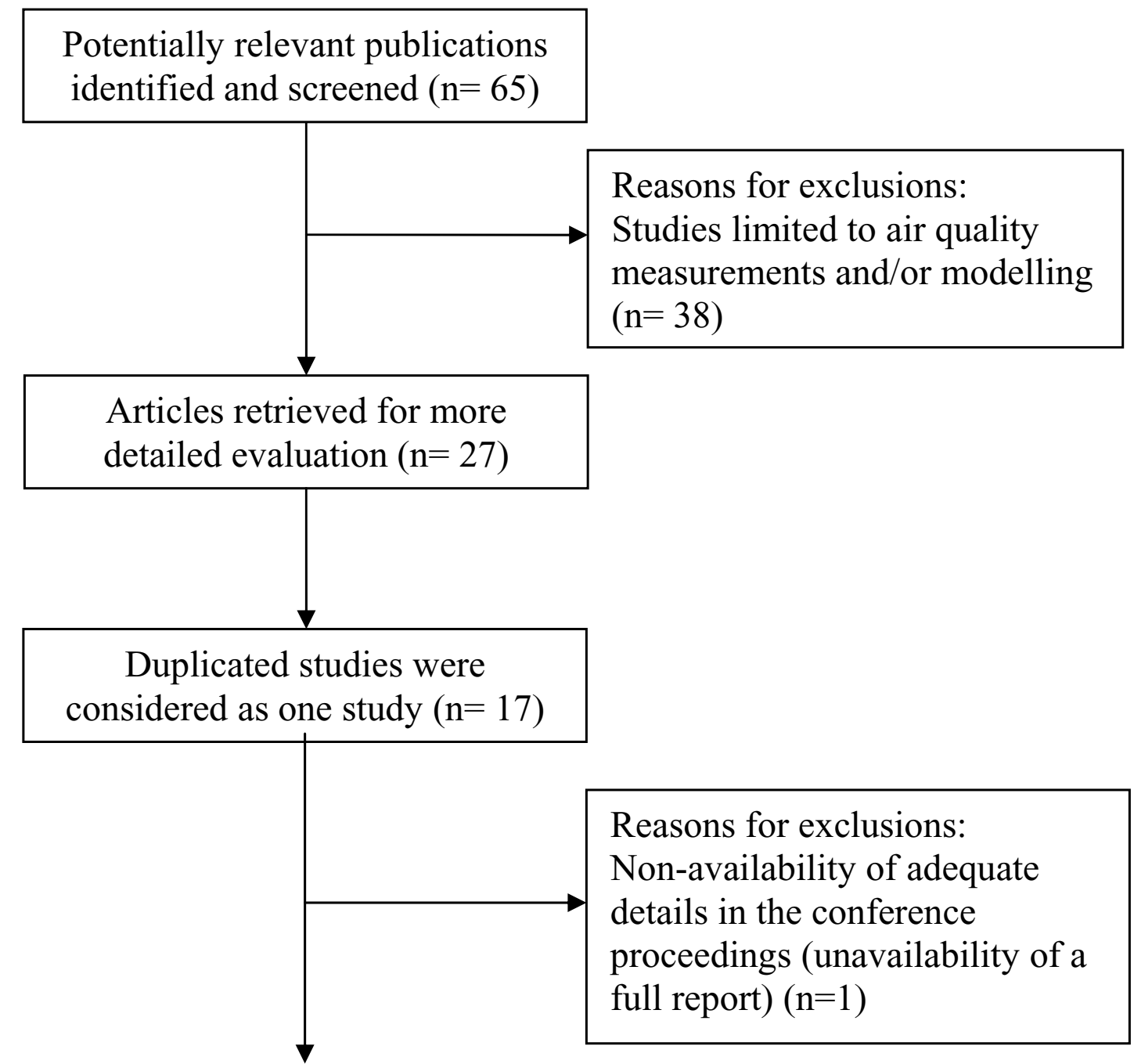

\section{Studies included $(\mathrm{n}=16)$}

Figure 4 Flow diagram of selection of studies

tation of the study as the total time spent at the school by a secondary school student is less than $15 \%$ for a one-year life span and the exposure levels in other living environments of the children were not considered. Further, considerable proportions of children in urban schools travel daily from rural locations with low outdoor exposure. Children from rural households may be exposed to more IAP due to more biomass fuel use in these areas.

Mistry R. et al. [32] compared the prevalence of asthma among 13 to 14 year-old children in Galle $(n=1162)$ (described by the authors as an unplanned, busy city with predominant use of kerosene or firewood for cooking in Sri Lanka) with Chandigarh $(\mathrm{n}=575)$ (a city defined by the authors as a planned, clean and using smoke-free household fuel in India). Children in Galle were at an increased risk for life-time wheezing (Galle-28.7\%, Chandigarh-12.5\%; the prevalence odds ratios $(\mathrm{POR})=2.3$, $95 \% \mathrm{CI}=1.8-2.9)$ and for wheezing in the previous year (Galle-21.9\%, Chandigarh-10.4\%, POR $=2.1,95 \% \mathrm{CI}=$ 1.6-2.7) as compared to children from Chandigarh. 
An ecologic study examined the air pollutant levels measured at the Colombo Fort monitoring station and rates of hospital attendance for wheezing needing emergency treatment at the Lady Ridgeway Hospital for Children in Colombo. About 30,932 children required nebulizer therapy in the emergency treatment unit (median daily attendance, $\mathrm{n}=85$ ) during the 12 -month period beginning in July 1998. The highest number of episodes of nebulization occurred on the most polluted day (with respect to $\mathrm{SO}_{2}$ and $\mathrm{NO}_{2}$ ) and the lowest number of nebulizations occurred on the least polluted day in a given week, in a significant number of weeks throughout the year (binomial test, $\mathrm{p}=0.05$ ) [33]. However, the actual exposure of all the patients admitted to this hospital probably did not represent the air quality of Colombo Fort monitoring station as the hospital is a referral centre for the whole country. Exposure data was limited to only a few pollutants.

Based on data of the Colombo Fort monitoring station, episodes of bronchitis, emphysema and other chronic obstructive pulmonary diseases had a strong association with $\mathrm{PM}_{10}$ levels (correlation coefficient $=0.717 ; \mathrm{p}=$ 0.01 ). Nearly $20 \%$ of asthma patients who visited the Lady Ridgeway Hospital for Children in Colombo in 2005 could be attributed to exposure to $\mathrm{PM}_{10}$ in Colombo based on the health impact assessment software developed by WHO [34]. Although the location of the Colombo Fort monitoring station may not represent the entire area of study population, this study provides evidence for implementation of early mitigation strategies.

Air pollutants were measured using passive samplers in Mount Lavinia, a metropolitan area bordering Colombo, to measure the 24-hour average levels among city dwellers engaged in different occupations[35]. Bus drivers were exposed to more $\mathrm{NO}_{2}\left(57.36 \mu \mathrm{g} / \mathrm{m}^{3}\right)$ and $\mathrm{SO}_{2}(82.70$ $\left.\mu \mathrm{g} / \mathrm{m}^{3}\right)$ as compared to trishaw drivers $\left(\mathrm{NO}_{2}-50.18 \mu \mathrm{g} /\right.$ $\left.\mathrm{m}^{3} ; \mathrm{SO}_{2}-78.36 \mu \mathrm{g} / \mathrm{m}^{3}\right)$, shop keepers $\left(\mathrm{NO}_{2}-54.91 \mu \mathrm{g} / \mathrm{m}^{3}\right.$; $\left.\mathrm{SO}_{2}-63.29 \mu \mathrm{g} / \mathrm{m}^{3}\right)$ and outdoor vendors $\left(\mathrm{NO}_{2}-37.66 \mu \mathrm{g} /\right.$ $\left.\mathrm{m}^{3} ; \mathrm{SO}_{2}-35.25 \mu \mathrm{g} / \mathrm{m}^{3}\right)$. Respiratory conditions were assessed in each participant using a questionnaire. The highest prevalence of respiratory symptoms was reported among bus drivers.

\section{Blood lead levels}

Following the introduction of unleaded gasoline, atmospheric lead levels reduced by $81.5 \%, 82 \%$ and $84 \%$ in three locations in Colombo [36]. Senanayake et al. [37] measured blood lead levels of a sample of children living near a traffic congested junction in Colombo in 1998 and then one year after the introduction of unleaded gasoline. In 1998, 6\% of children had blood lead levels above $10 \mu \mathrm{g} /$ $\mathrm{dL}$; in 2003, not a single child had a blood lead level $>10$ $\mu \mathrm{g} / \mathrm{dl}$ (range $1.67 \mu \mathrm{g} / \mathrm{dl}$ to $9.7 \mu \mathrm{g} / \mathrm{dl}$ ).
Amarasinghe et al. [38] measured blood lead levels of traffic policemen $(n=64)$ and non traffic policemen $(n=$ 64) based in Colombo. The mean blood lead levels in traffic and non-traffic policemen were $7.47 \mu \mathrm{g} / \mathrm{dl}(\mathrm{SD}=2.89)$ and $7.06 \mu \mathrm{g} / \mathrm{dl}(\mathrm{SD}=2.93)$, respectively. Abdominal discomfort, tremor and hypertension were higher in traffic policemen as compared to non-traffic policemen, although the differences were not significant. There may be exposure misclassification as non-traffic policemen are duty bound to control traffic during busy hours.

\section{Studies on Indoor Air Pollution}

We reviewed 6 studies that have evaluated IAP and health outcomes in Sri Lanka. Of the 6 studies, 3 were case-control studies and 3 were cross-sectional studies. Five of the 6 studies used proxy measurements for IAP and no quantitative measurements were undertaken. There was no adjustment done for potential confounding factors.

\section{Respiratory Health}

A hospital-based case-control study [39] of 300 subjects (age-matched) found that the presence of dust at home was a significant risk factor (adjusted OR $=1.3,95 \% \mathrm{CI}=$ 1.02 - 2.1) for asthma. There may have been potential exposure misclassification and recall bias with cases overreporting a "dusty environment".

A cross-sectional study conducted in a Colombo suburb reported that the use of fire wood for cooking was a significant risk factor for respiratory symptoms $(\mathrm{OR}=$ 1.61; $95 \% \mathrm{CI}=1.3-2.53$ ) [20]. Average TSP levels in houses using firewood were $0.606 \mathrm{mg} / \mathrm{m}^{3}$ and in houses not using firewood were $0.245 \mathrm{mg} / \mathrm{m}^{3}$. The respirable dust concentration exceeded the WHO standards in $84 \%$ of households using firewood and 54\% of the households not using firewood [20].

Another school-based cross-sectional study of asthmatics $(\mathrm{n}=441)$ and non- asthmatics $(\mathrm{n}=1510)$ in the Gampaha district reported that the presence of firewood smoke in the bed room while cooking (OR 1.4, 95\% CI 1.1-1.9), use of mosquito coils (OR 1.5, 95\% CI 1.2 - 1.9), and a dusty environment (OR 1.8, 95\% CI 1.4 - 2.3) significantly increased the risk of asthma. No air pollutant measurements were done. The environmental exposure assessment was based on a questionnaire and no adjustment for confounding factors was done [40].

\section{Cataract}

Ranasinghe et al. [41] reported an association ( $\mathrm{p}<0.05)$ between biomass exposure and cataract by comparing cataract patients (cases, $\mathrm{n}=197$ ) with patients admitted to the National Eye Hospital, Colombo, for other eye problems (controls, $\mathrm{n}=190$ ). The biomass exposure assessment was solely based on a questionnaire.

\section{Lung Cancer}

Perera et al. [42] investigated the association between exposure to biomass smoke and lung cancer. The major- 
ity of the population (more than 50\%) was between the ages of 41-50 years and male; the majority of the cases were directly exposed to tobacco smoke (48\%). There was an association between smoking and lung cancer $(\mathrm{p}=$ $0.04)$ but not with biomass fuels use $(\mathrm{p}=0.10)$. Exposure was assessed using a questionnaire.

\section{Low Birth Weight}

A cross-sectional study [43] reported that the availability of a separate kitchen $(\mathrm{OR}=2.7,95 \% \mathrm{CI}=1.6-4.7)$, using less clean cooking fuel $(\mathrm{OR}=3.9,95 \% \mathrm{CI}=1.8-8.5)$ and not having adequate ventilation in the cooking area $(\mathrm{OR}=$ $2.7,95 \% \mathrm{CI}=1.3-5.3$ ) were significant predictors of low birth weight in the Kegalle and Kalutara districts. Air quality measurements were not reported in this study.

\section{Confounders}

Several studies[28,30,35,39,40] adjusted for common confounders such as second-hand smoke exposure, cooking fuel type, mosquito coil use etc., proxy measures for indoor air quality. The air quality levels in studies that measured air quality $[20,30,34,35]$ were similar to those reported in other countries.

\section{Strengths and Weaknesses}

We did not use strict inclusion criteria as our primary objective was to explore most of the studies done in Sri Lanka relevant to the subject. We included studies that used only proxy variables as the number of studies that measured actual air quality was limited. We had no option but to include as many studies as possible due to the limited number.

\section{Future Perspectives}

The broad range of likely health impacts of air pollution in Sri Lanka means that a variety of methods and strategies should be applied for mitigating adverse health effects and minimizing exposures. Generating baseline data related to indoor and outdoor air pollutants and human health will form the platform to address this problem at national, community and individual level. It will be the basis for advocacy, formulating mitigation strategies and minimizing exposure.

The lack of a proper air quality monitoring system to track human exposure is a major limitation. This has to be addressed to determine the impact of programmes and to identify the future directions. The availability of stringent standards by itself is of no use if the air quality that citizens are exposed to is unknown to identify areas for intervention using an evidence based approach. Therefore, establishing a modern ambient air quality monitoring network, at least covering the main busy cities in the country, is an early need.

Although several activities have been implemented to reduce outdoor air pollution, there are no specific inter- ventions implemented at national level to reduce IAP or to minimize the exposure of vulnerable groups to indoor air pollutants. There is a lack of reliable indoor air quality data and determinants of indoor air quality in Sri Lanka, a priority that needs to be addressed when estimating the burden of disease associated with IAP. Enactment of new laws and enforcing existing laws will require reliable baseline data on indoor and outdoor air quality and health impact. Practices and other determinants that increase human exposure to air pollutants need to be identified in local communities. Robust research studies should be designed to generate individual exposure data, identify and evaluate determinants associated with air pollution exposures and to quantify the public health effects of such exposures in Sri Lanka. Public health impact of outdoor air pollution control activities should be assessed to monitor and modify such mitigation activities.

Modifying existing regulatory practices based on findings of robust research studies, strict adherence to regulations at community and household level and identifying new mitigation strategies can play a key role in minimizing the impact of air pollution on health.

\section{Conclusions}

Despite inconsistencies, findings from Sri Lankan studies generally suggest that air pollution, both ambient and indoor, is a major public health problem in Sri Lanka. The results of these studies could be used as a base to design larger epidemiologic investigations to address the problems of measurement error, reduce uncertainties in risk estimates and identify the determinants of exposures.

\section{Competing interests}

The authors declare that they have no competing interests.

\section{Authors' contributions}

YLNS, ARW and NS designed the study. YLSN completed the initial literature survey. YLSN and ARW summarized all eligible papers, synthesized the findings and drafted the manuscript. NS helped in drafting the final manuscript. YLSN is the guarantor of the work. All authors read and approved the final manuscript.

\section{Acknowledgements}

We acknowledge the support of the University of Alabama at Birmingham (UAB) International Training and Research in Environmental and Occupational Health (ITREOH) program, Grant Number 5D43TW05750 from the Fogarty International Center of the National Institutes of Health and to NASA. The content is solely the responsibility of the authors and does not necessarily represent the official views of UAB, Fogarty International Center, or the National Institutes of Health. Authors thank the Central Environmental Authority of Sri Lanka for providing necessary information.

\section{Author Details}

1Evaluation and Research Unit, National Institute of Health Sciences, Ministry of Health, Kalutara, Sri Lanka, ${ }^{2}$ Department of Public Health, Faculty of Medicine, University of Kelaniya, Kelaniya, Sri Lanka and '3Department of Epidemiology, School of Public Health, University of Alabama at Birmingham, Birmingham, USA

Received: 12 December 2009 Accepted: 2 June 2010 Published: 2 June 2010 


\section{References}

1. Bruce N, Perez-Padilla R, Albalak R: The health effects of indoor air pollution exposure in developing countries. Geneva: World Health Organization; 2002:11.

2. Senevirathne SRDA: Air pollution: a case study of environmental pollution. Journal of College of Community Physicians of Sri Lanka 2003, 8(1):1-9.

3. American Thoracic Society: What Constitutes an Adverse Health Effect of Air Pollution? American Journal of Respiratory Critical Care Medicine 2000, 161:665-673.

4. HEl: Special Report 15, Health Effects of Outdoor Air Pollution in Developing Countries of Asia: A literature Review. Health Effects Institute; 2004.

5. WHO: Health Aspects of Air Pollution: Results from the WHO project " Systematic Review of Health Aspects of Air Pollution in Europe". Europe: World Health Organization; 2004

6. Batagoda B, Sugathapala A, Yalegama M, Jayasinghe B: Urban Air Quality Management in Sri Lanka. Colombo: Air Resource Management Center (AirMAC), Ministry of Environment and Natural Resources, Sri Lanka; 2004:iii.

7. The National Environmental Act, No. 47 of 1980: Amendment to the National Environmental (Ambient Air Quality) Regulations, No 817/6Tuesday, May 03, 1994. In Volume No 817/6-Tuesday, May 03, 1994 Government Notification: The Gazette of the Democratic Socialist Republic of Sri Lanka; 1994.

8. WHO: WHO Air quality guidelines for particulate matter, ozone, nitrogen dioxide and sulfur dioxide, Global update 2005, Summary of risk assessment. Geneva: World Health Organization; 2005

9. The National Environmental Act, No. 47 of 1980: Amendment to the National Environmental (Ambient Air Quality) Regulations, No 1562/ 22-Friday, August 15,2008. Government Notification: The Gazette of the Democratic Socialist Republic of Sri Lanka; 2008.

10. Hopke PK, Cohen DD, Begum BA, Biswas SK, Ni B, Pandit GG, Santoso M, Chung YS, Davy P, Markwitz A, et al.: Urban air quality in the Asian region. Sci Total Environ 2008, 404(1):103-112.

11. Air Quality in Asian Cities [http://www.cleanairnet.org/caiasia/1412/ articles-59689 AlR.pdf]

12. Jayaratna RNR, lleperuma OA: Air Quality Trends and Variation Pattern of Air Pollutants in the City of Colombo. "Air That We Breath", Third National Symposium on air resource management in Sri Lanka: 2007; Colombo 2007.

13. Jayawardana KGS, Jayaratna RNR: What Colombo's Air Quality Tell Us. "Air That We Breath", First National Symposium on Air Resource Management in Sri Lanka 2004; Colombo 2004.

14. Samarakkody RP, Premasiri HDS, Annakkage CJ, Basnayake GBMA: Identification of Critical and Shrinking Areas in Colombo by Means of Spatial Air Quality Monitoring. "Air That We Breathe", First National Symposium on Air Resource Management in Sri Lanka: 2004; Colombo 2004

15. Mallikarachchi BS, Manawadu L, Samarakkody RP: Identification of Air Pollution Potential Areas and Its Temporal and Partial Pattern of the City of Colombo - Applying GIS. "Air That We Breath", First National Symposium on Air Resource Management in Sri Lanka 2004: 2004; Colombo 2004

16. Manawadu L, Wijesekara KASS: Understanding Air Pollution Dynamics and Exploring Reasons for Aggravation of Air Pollution in the City of Colombo Using Geo-Statistical Techniques. "Geo-Informatics For National Development", The Sixth National Symposium on Geo-Informatics. 2009; Colombo 2009:17-32

17. Mitchell CS, Zhang J, Sigsgaard T, Jantunen M, Lioy PJ, Samson R, Karol $\mathrm{MH}$ : Current State of the Science: Health Effects and Indoor Environmental Quality. Environmental Health Perspectives 2007 115(6):958-964

18. WHO: Monitoring ambient air quality for health impact assessment. In European Series Copenhagen: Regional Office for Europe; 1999:9. 14,19

19. Samarakkody RP, Fernando ATR: Measuring of Nitrogen Dioxide Exposure Levels - A Quick Test for Air Pollution. "Air That We Breath", Third National Symposium on air resource management in Sri Lanka: 2007; Colombo 2007.

20. Lankathilaka KN, Seneviratne SRDA, Fernando DN: Indoor air quality and respiratory symptoms among children and women. Sri Lanka Association for the Advancement of Science - 56th Annual Session. Volume Part - 1 abstract. Colombo 2000
21. Bruce N, Perez-Padilla R, Albalak R: Indoor air pollution in developing countries: a major environmental and public health challenge. Bulletin of the World Health Organization 2000, 78(9):1078-1092.

22. Demographic and Health Survey 2006/2007, Preliminary Report [http://www.statistics.gov.lk]

23. Nandasena YLS, Wickremasinghe AR, Sathiakumar N: Socio-demographic characteristics and principal cooking fuel type in Sri Lanka: Comparison of data from two Demographic and Health surveys. 14th Annual Academic Sessions of College of Community Physicians of Sri Lanka: 2009; Colombo 2009.

24. Amerasekera RM: Proven interventions to reduce indoor air pollution due to cooking with biomass. "Air That We Breath", First National Symposium on Air Resource Management in Sri Lanka: 2004; Colombo 2004.

25. Senanayaka MP, Samarakkody RP: Impact of outdoor and Indoor air pollution on personal exposure of 5 - 8 year old children living in low income settlements in Colombo. "Air That We Breathe", First National Symposium on Air Resource Management in Sri Lanka. Colombo 2004.

26. National authority on tobacco and alcohol act, no. 27 [http:// www.documents.gov.lk/actspg/acts2006-2.htm]

27. Gunasekara P, Rahman K, Warren C, Lee J, Lea V, Asma S: Tobacco use among students aged 13-15 years--Sri Lanka, 1999-2007. MMWR Morbidity and Mortality Weekly Report 2008, 57(20):545-549.

28. Sirithunga TLC, Kumarasiri RPK, Illeperuma OA: Effects of outdoor air pollution on the respiratory health of children in a rural and an urban area in the Kandy district. "Air That We Breath", Second National Symposium on Air Resource Management in Sri Lanka: 2006; Colombo 2006.

29. Premaratna R, Pathmeswaran A, Chandrasekara B, Dissanayake AS, Silva HJD: Effects of Pollution on Health of Residents in an Industrial Area in Sri Lanka. Archives of Environmental Health 2002, 57(6):579-583.

30. Nandasena YLS, Perera GBS, Emmanuel R, Premasiri HDS: Exposure to aerosol pollution and reported respiratory symptoms among school children in segments of urban and rural settings in Sri Lanka. "Air That We Breath", Third National Symposium on air resource management in Sri Lanka: 2007; Colombo, Sri Lanka 2007

31. Elangasinghe MA, Shanthini R: Traffic Related Air Pollution And Respiratory Related Health of Students Attending School in Kandy. "Air That We Breath", Second National Symposium on Air Resource Management in Sri Lanka: 2006; Colombo 2006.

32. Mistry R, Wickramasingha N, Ogston S, Singh M, Devasiri V, Mukhopadhyay S: Wheeze and urban variation in South Asia. Eur Pediatr 2004, 163(3): 145-147.

33. Senanayake MP, Samarakkody RP, Sumanasena SP, Kudalugodaarachchi J, Jayasinhe SR, Hettiarachchi AP: A relational analysis of acute wheezing and air pollution. Sri Lanka Journal of Child Health 2001, 30(2):66-68.

34. Thishan Dharshana KG, Coowanitwong N: Ambient PM(10) and respiratory illnesses in Colombo City, Sri Lanka. J Environ Sci Health A Tox Hazard Subst Environ Eng 2008, 43(9):1064-1070.

35. Perera GBS, Emmanuel R, Nandasena YLS, Premasiri HDS: Exposure to aerosol pollution and reported respiratory symptoms among segments of urban and rural population in Sri Lanka. Built Environment Sri Lanka 2007, 7(2):31-39.

36. NBRO: Changing atmospheric lead levels in Colombo with discontinuation of leaded petrol in Sri Lanka. In Division of Environment Colombo: NBRO; 2003

37. Senanayake MP, Rodrigo MDA, Malkanthi R: Blood lead levels of children before and after introduction of unleaded petrol. Ceylon Medical Journal 2004, 49(2):60-61.

38. Amarasinghe JNP: Blood lead levels of traffic policeman in the city of Colombo. University of Colombo, Postgraduate Institute of Colombo: 2002.

39. Karunasekara KAW, Jayasinhe JA, Alwis LW: Risk factors of childhood asthma: a Sri Lankan study. Journal of Tropical Pediatrics 2001, 47(3):142-145.

40. Karunasekara KAW, Perera KPJ, Perera MTPR, Abeynarayana J: Genetic and environmental risk for asthma in children aged 5-11 years. Sri Lanka Journal of Child Health 2005, 34:79-83.

41. Ranasinghe MH, Mahanama KRR: Risk of Cataract Formation with Exposure to Biomass Smoke. "Air That We Breath", First National Symposium on Air Resource Management in Sri Lanka: 2004; Colombo 2004 
42. Perera MAKKP, Mahanama KRR: Investigation of Lung Cancer to Human Activities in Sri Lanka. "Air That We Breath", First National Symposium on Air Resource Management in Sri Lanka: 2004; Colombo 2004.

43. Pathirane SM, Mahanama KRR: Low Birth Weights of Infants and

Exposure to Smoke from Biomass Fuel during Pregnancy. "Air That We Breath", Second National Symposium on Air Resource Management in Sri Lanka 2006: 2006; Colombo 2006

Pre-publication history

The pre-publication history for this paper can be accessed here: http://www.biomedcentral.com/1471-2458/10/300/prepub

doi: $10.1186 / 1471-2458-10-300$

Cite this article as: Nandasena et al., Air pollution and health in Sri Lanka: a review of epidemiologic studies BMC Public Health 2010, 10:300

Submit your next manuscript to BioMed Central and take full advantage of:

- Convenient online submission

- Thorough peer review

- No space constraints or color figure charges

- Immediate publication on acceptance

- Inclusion in PubMed, CAS, Scopus and Google Scholar

- Research which is freely available for redistribution

Submit your manuscript at www.biomedcentral.com/submit
C Biomed Central 